\title{
OCCLUSIONS OF THE OPERATIONAL SEQUENCE: A COINCIDENTAL CONVERSATION BETWEEN ROBERT MATTHEW AND ANDRÉ LEROI-GOURHAN IN SIX DIAGRAMS
}

\begin{abstract}
Alessandro Zambelli
Architectural Humanities and Professional Practice, School of Architecture and Design, University of Brighton,

England, UK

Email: a.zambelli@brighton.ac.uk

In the 1960s, with western narratives of technical progress at their height, Robert Matthew, then president of the Royal Institute of British Architects, and anthropologist Andre Leroi-Gourhan independently advocated totalising, systematic, technical models of human progress. Each model a reflection of the aims and methods of their own discipline: for the anthropologist, the evolution of Homo sapiens from Homo faber and the dissolving of human/technological boundaries; for the architect, a "collective welfare-socialism" and the systematisation of its built manifestations. Each of these models made manifest, I argue, through profoundly influential diagrams. Leroi-Gourhan's chaîne opératoire describes the manufacture of prehistoric stone tools whilst the RIBA's Plan of Work describes the design and construction of buildings. Through the embodied objects and processes of these diagrams this paper sees "chaine" and "Plan" engaging in a kind of reciprocating exchange: a diagrammed conversation revealing, for each discipline, processes occluded or overlooked in the other.
\end{abstract}

Keywords: anthropology; archaeology; architecture; chaine opératoire; design; reconstruction Article History: Received 31 March 2017; accepted 26 June 2017

Management techniques misapplied wreak havoc among the complex and highly charged relationships of the design group. But scientific management, like matrix algebra, is one of those $20^{\text {th }}$ century facts of life with which the architect, for good or ill, must come to terms. It is no more sensible to reject its usefulness out of hand than it would be to deny oneself the possibility of using thin concrete shells and stick to mud walls and thatch. ${ }^{1}$

Architectural Theory Review, 2017, Vol. 21, No. 21, pp. 1-23 https://doi.org/10.1080/13264826.2017.1350728 
[...] we arrived at the concept of tools as being a "secretion" of the anthropoid's body and brain. If that is so, then it is logical that the standards of natural organs should be applied to such artificial organs: They must exhibit constantly recurring forms, their nature must be fixed. The same rule in fact applies to all products of human industry in historic times: There exists a stereotype of the knife, the ax, the plough, or the aircraft that is not only the product of a coherent intelligence but is also integrated in a substance and a function. ${ }^{2}$

Launched in 1965, R. Buckminster Fuller's Design Science Decade ${ }^{3}$ witnessed the application of scientific method to the production of new tools not only for design disciplines such as architecture, but also for disciplines rarely categorised as creative and propositional, such as anthropology and archaeology. ${ }^{4}$ I will argue, and have argued elsewhere, ${ }^{5}$ that the comparison and analysis of these tools reveals hitherto occluded coincidences between them. Architecture and anthropology developed independently, at more or less the same time, diagrams of processes intimately associated with their respective "parent" discipline. In the case of architecture, the Plan of Work describes key disciplinary processes and, in particular, how one might "procure" a building. In the case of anthropology, the diagrams, instead, set out how one might describe the processes of artefactual production, usually stone implements, of a given culture, and how those processes might be a reflection of, and also a tool for, understanding certain aspects of that culture.

Scottish architect Robert Matthew, then president of the Royal Institute of British Architects (RIBA), and French anthropologist André Leroi-Gourhan independently advocated totalising, systematic, technical models of human progress. Each model was a reflection of the aims and methods of their own discipline: for the anthropologist, this was the evolution of Homo faber into Homo sapiens and the dissolying of human/technological boundaries and, for the architect, the necessary drive, as Matthew saw it, for "collective welfare-socialism" and the systematisation of its built manifestations. For each discipline, their model was represented by a diagram or, more accurately, by eyolving sequences of diagrams. Leroi-Gourhan's schematisation of prehistoric lithic production was called the chaîne opératoire and Matthew's building construction sequence, simply, the "Plan of Work".

The Plan of Work was much anticipated by the architectural profession in the United Kingdom. The ideals it represented spoke directly to that generation of architects who had endured the war, enjoyed the promise of reconstruction embodied, for example, in the 1951 Festival of Britain, ${ }^{7}$ and who desired nothing more than that the hegemony of science, and the science of systems, be allowed to restore order to the post-war chaos; "these projections stressed progress and modernity, with science and planning evoked as the answers to the question of how to build a better Britain". 8 These architects saw no problem in the ushering-in of a technological "turn" to their art; "because architecture is one of the arts", wrote Donald Gibson, Matthew's successor as RIBA president, "there need be no doubt that they are compatible; management; which is both an art and a skill, is the creation of conditions in which material and human resources can be used to the greatest effect". ${ }^{9}$ Indeed, Miles Glendinning claims that Matthew "restructured the RIBA 
around [the Plan of Work]", ${ }^{10}$ and that "it was Matthew's own presidency that finalised the RIBA's transformation from a 'moribund learned society' into an influential, modern institution". ${ }^{11}$

The systematisation of disciplinary aims, as much as the understanding of disciplinary objects through tools of systematisation, became widespread in the decades immediately following World War II. British and French social anthropology began to split from an American anthropology described by Erwan Dianteill as "open to psychology, archeology, geography, technology, history, aesthetics and the humanities in general". ${ }^{12}$ For Claude Levi-Strauss, "in 1950, anthropology was therefore still both social and cultural [...]. Ten years later, however, it was a chair of social anthropology that was created at the Collège de France, and it was there that LéviStrauss set up a laboratory of social, not cultural, anthropology". ${ }^{13}$ In the UK, Max Gluckman, Edmund Leach, and others were responsible for bringing Levi-Strauss' brand of structuralism to British social anthropology, ${ }^{14}$ holding that "anthropology is a social science, closely related to sociology, psychology, economics, politics, law, and history [...] only distantly related to biological anthropology, technology, or archaeology". ${ }^{15}$ In particular, Gluckman's Manchester School began interrogating, amongst other things, tensions between the agency of the individual and wider social structures, understanding "social structure as a progressive system through time". ${ }^{16}$ Driven by pioneering fieldwork led by Gluckman, the 1950s and 1960s in the UK were characterised by a strand of anthropological theory specifically concerned with the "management of systems" ${ }^{17}$ Leroi-Gourhan, for his part, was never easily aligned with either American (cultural) or European (social) systems, "borrow[ing] from philosophy, social anthropology, prehistory, paleontology, and biology", argues Francois Audouze, "without adopting the full theoretical framework and practice of any of them". ${ }^{18}$ And, as I will argue, his chaine opératoire is an apt reflection of this socio-cultural eclecticism.

"The diagram is no longer an auditory or visual archive but a map, a cartography that is coextensive with the whole social field", claims Gilles Deleuze, "it is an abstract machine. It is defined by its informal functions and matter and in terms of form makes no distinction between content and expression, a discursive formation and a non-discursive formation. It is a machine that is almost blind and mute, even though it makes others see and speak. What is a diagram? It is a display of the relations between forces which constitute power" ${ }^{19}$ That diagrams embody and project authority is well-understood. Christoph Lueder argues for "the fundamentally relational identity of diagrams [...] places them in a supporting role, but also at pivotal, if not always acknowledged, positions within ecologies of thought. Hence, diagrams provide auspicious vantage points for describing and understanding such ecologies". ${ }^{20}$

Figure 1 shows a simple, generic example of a chaîne opératoire diagram alongside the R.I.B.A.s Plan of Work "motif", but what kinds of objects or things are these anthropological and architectural diagrams? For anthropologist Tim Ingold, both Plan and chaine conform to the Aristotelian category of the "hylomorphic" under which "form came to be seen as imposed, by an agent with a particular end in mind, while matter - rendered passive and inert-was that which was imposed upon". ${ }^{21}$ Instead, in Ingold's view, "the inhabited world is comprised not of objects but of things" and "a focus on life-processes requires us to attend not to materiality as such but to the fluxes and flows of materials. This means moving with them, and following 
their ways". Anthropological diagrams, on the other hand, tend, for Ingold, towards the static, the lifeless: "anthropologists do just the same when they draw genealogical diagrams of kinship and descent. The lines of the kinship chart join up, they connect, but they are not lifelines or even storylines. It seems that what modern thought has done to place-fixing it to spatial locations - it has also done to people, wrapping their lives into temporal moments". 22 Although the diagrams drawn upon below are undoubtedly, in their unreflective instrumentality, "objects" rather than "things" in the sense in which Ingold uses the term, their "fluxes and flows" are, I would argue, more reminiscent of the "mantic operations" Marco Frascari describes in relation to architectural design. The "mantic" or divinatory process of design is here seen as the ritualised use of "analogous instruments" such as drawings. These drawings-as-instruments, for Frascari, seem to probe time and space searching for an opportunity to manifest themselves as buildings:

An architectural projection is graphically divined through rules when the opportunity for construction arises. The translation of edifices into drawings and of drawing into edifices is the foundation of the mantic paradigm in architecture..$^{23}$

Here, the architect's secret knowledge manifested in drawing and drawings enables them to see the invisible (draw a plan by observing only the outside of a building), see backwards in time (draw a ruined building as if it were complete), and to see the future (design a building). ${ }^{24}$ Alongside drawings, I would argue, the RIBA Plan of Work is another such mantic, divinatory, "analogous instrument". In this account, the Plan and the chaîne are not simply dumb representations of pre-existing systems - typical design and building processes, or typical stone tool production-they give force to those systems and presence to the objects of them. Leroi-Gourhan emphasises that for him, "the tool [...] is only a testimony of the exteriorisation of an efficient gesture $[\ldots]$ it is the materialization of the interaction of matter with the means to transform it" ${ }^{25}$ Here, the "gesture" has the architectural instrumentality of Marco Frascari's architectural "mantic operation requiring careful timing and specific opportunities". ${ }^{26}$

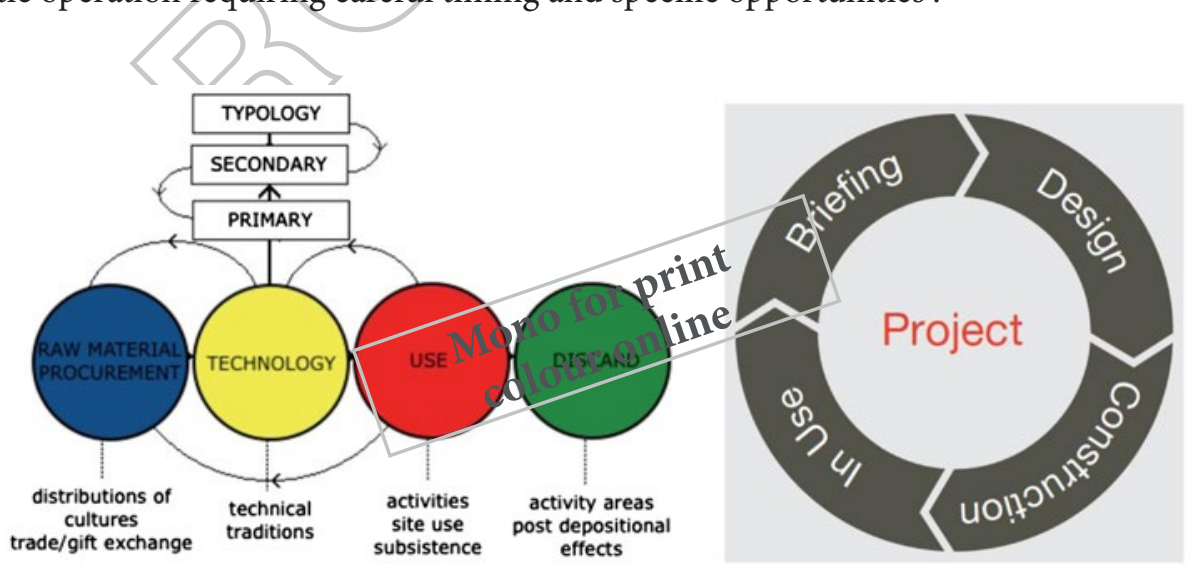

Figure 1. Left: Chaîne opératoire, Roger Grace, 2012 [1997]. Right: Simplified motif of the RIBA Plan of Work 2013. 
At times, both architecture and anthropology have sought to assume the role of meta-discipline, ${ }^{27}$ a condition making them simultaneously resistant to structural change, yet also porous to other disciplines - in this sense, they are both examples of what Mark Cousins would describe as "weak discipline $[\mathrm{s}]$ ". ${ }^{28}$

As a purely anecdotal example, I witnessed an exchange at a symposium in Scotland a few years ago between an architect and an anthropologist, where the architect, convinced, silently up until this point, of the superiority of the "meta"-ness of his discipline and in some frustration at the course the conversation had been taking, exclaimed, "ok, but then what do you do with all of that information? - we then propose something!" 29 This sort of disciplinary protectionism has some history: "Mr. Giedion is no prehistorian", ${ }^{30}$ exclaimed the anthropologist (and prehistorian) André Leroi-Gourhan in a somewhat scathing review of his erstwhile friend's The Eternal Present. ${ }^{31}$ Sigfried Giedion had been indulging his considerable expertise in visual history and architectural criticism somewhat outside of his disciplinary comfort zone, and where it coincided with that of the eminent paleo-ethnographer, he had been called to account. $^{32}$

Would Leroi-Gourhan have recognised the Plan of Work, then, as an example of "cultural technology", as a tool of Homo faber? ${ }^{33}$ Leroi-Gourhan's defining work from 1963-1964, Le Geste et la Parole, with its nascent "operational sequence", or chaîne opératoire, suggests, I will argue, that he might. Leroi-Gourhan was a polymath whose fields of expertise are described differently depending upon which discipline any particular commentator happens to be writing about, although, other than his relationship with Sigfried Giedion, he is not known to have harboured any particular architectural interests. The Plan of Work, on the other hand-that diagram of, and armature to, a typical (contemporary, complex) construction project-would surely have spoken directly to Leroi-Gourhan's desire to formalise human technical processes. Francoise Audouze describes Leroi-Gourhan as the "creator of the discipline of cultural technology; and renovator of the study of prehistory with his novel approach to 'paleoethnology' or prehistoric ethnology" ${ }^{34}$

The chaîne opératoire is generally understood to be the formalised and abstracted "sequence of actions" ${ }^{\prime 3}$ necessary and sufficient to describe the entire life-cycle of an archaeological artefact. A method for analysing the prehistorical past, it was conceived of, initially, by Marcel Mauss, "who had [...] recognised the benefits of understanding a society through its techniques". ${ }^{36}$ Later, it was more fully established and named the chaîne opératoire by Leroi-Gourhan ${ }^{37}$ and then further systematised by Jacques Tixier, amongst others. ${ }^{38}$ This "trend in French ethnology" towards a technical understanding of culture, wrote Marie-Louise Inizan, "contributed to the emergence of a 'school of cultural technology' [which helped] to rehabilitate the study of material culture, by demonstrating that any technical fact is a social or a cultural fact". ${ }^{39}$ As Renfrew and Bahn have it, "the analytical concept of chaîne opératoire [...] has been developed to make more explicit the cognitive implications of the complicated and often highly standardized sequence of events", and that, "for early periods, such as the Paleolithic, this approach offers one of the few 
insights available of the way cognitive structures underlay complex aspects of human behavior" ${ }^{40}$ Architectural Plans of Work, I would argue, are never seen in this way because, as I have argued elsewhere, ${ }^{41}$ the connections, between the disciplines of architecture, anthropology, and archaeology in particular - of their interconnected origins and development-have become obscured across time. But allowed to influence one another-to be in the same room "in conversation" together, as it were-they might be seen this way.

The Plan was updated in $1967,1973,{ }^{42} 1998$, unofficially in $2000,{ }^{43}$ more deeply in 2007 , and most radically in 2013, yet, at first glance, it seems to have changed very little. This stability underlies, perhaps, the reason that the RIBA's model has seen extensive use outside of the UK. ${ }^{44}$ Just like the anthropological chaîne opératoire and its "enlightening concepts and theories about technical processes, imitation, and innovation" ${ }^{45}$ the architectural Plan of Work also relies upon the reproducibility implicit in this "imitation" to make it the powerful, exportable, and persistent technical tool that it has proved to be. Would Leroi-Gourhan have seen the Plan of Work as part of Bernard Stiegler's "unity of techniques present all over the world and evolving everywhere in a comparable way"? ${ }^{46}$ Certainly, its authors, as we shall see, were keen that its use would tie together otherwise disparate design and construction techniques and processes. They would have been convinced of this unity because they would have seen technical efficiency, even its hegemony, as an inherent desire of all peoples and a necessary precursor to the "collective welfare-socialism" ${ }^{\prime 7}$ Matthew so strongly believed in. Yet, Leroi-Gourhan's evolutionary argument would see this as simply one stage of a process of development; it would have "considered the social body as a prolongation of the anatomical body" 48

For Leroi-Gourhan, the cultural and the social must completely replace or overlay the natural. As Carrie Noland frames the problem, "thus, the most urgent question Leroi-Gourhan raises [...] is whether humans, through their development of increasingly sophisticated tools, eventually render their current form of embodied existence obsolete", and she then asks the question using Stiegler's language: "at what point does the machine (in Stiegler's terms, the "what") begin to define the human subject (the "who") with whom it is inextricably intertwined?" In Catherine Ingraham's alternative formulation, "the moment of humanness that is marked by standing up is also, for Leroi-Gourhan, the beginning of a withdrawal of the biological human body from

30 the process of evolution" ${ }^{49}$ For Ingraham, this loss is an "externalization into the environment or milieu in which that being lives" ${ }^{50}$

Increased mechanisation and systematisation of technical processes are also accounted for in Leroi-Gourhan's narrative, "[it is] a liberation so great in present-day societies that both tool and gesture are now embodied in the machine, operational memory in automatic devices, and programming itself in electronic equipment", ${ }^{51}$ and that "with the emergence of the percussion tool, the chopper and the antler employed for a practical purpose, a perceptible shift took place, cutting, crushing, molding, scraping, and digging operations were transferred to tools. The hand ceased to be a tool and became a driving force". ${ }^{52}$ If, according to Leroi-Gourhan, tools are a mediating technology between an "interior" and this "exterior milieux", 53 then it becomes possible to see not only the chaîne as a map of just such a technology (as it was meant to be), 
but also the Plan of Work similarly laying out a schema for the human-mediated technologies of the building construction process.

The Plan of Work and the various diagrams of the chaine opératoire as simultaneously products of, and drivers for, key aspects of their respective disciplines are, I would argue, indexes of those disciplines and, through brief analyses of six key diagrams of both types, I will begin to map their similarities and differences. One can see the RIBA Plan of Work and the chaîne opératoire engaging in a kind of abbreviated, diagrammed conversation, revealing occluded disciplinary aims, or offering to each other alternative ways of apprehending otherwise conventional processes. These 'revelations' are precipitated only through their interdisciplinary use or analysis, by allowing them to talk to each other.

DIAGRAM 1: 1963

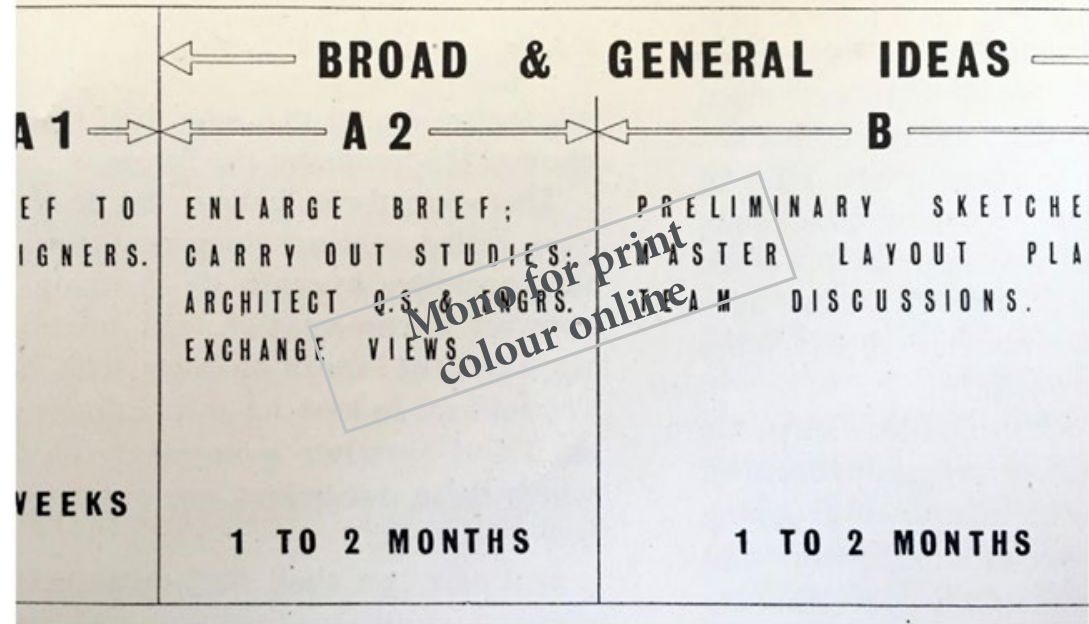

Figure 2. Plan of Works presented by C. E. D. Wooster.

In 1961, it fell to London to host the triennial Congress of the International Union of Architects (UIA). Called Architecture and Technology (New Techniques and New Materials), this event exemplified the trend in political and cultural milieux, and in particular in architecture and anthropology, to see technology-the techniques of Homo sapiens-as the new over-arching human paradigm. ${ }^{54}$ The following year, Robert Matthew assumed the presidency of the RIBA, a tenure which overlapped with the UK's presidency of the UIA, ${ }^{55}$ a coincidence which strengthened the growing technocratic trajectory of the project of modern design, and architecture in particular.

The RIBA's own Plan grew from the 1962 Conference on Design Methods, also held in London ${ }^{56}$ and "generally regarded", writes Nigel Cross, "as the event which marked the launch of design methodology as a subject or field of enquiry". ${ }^{57}$ Meanwhile, in July 1963, at the RIBA Annual Conference, held that year in Sheffield, C. E. D. Wooster, director of Building Management 
from the Ministry of Public Building and Works, introduced the prototype Plan of Works, as it was called then (Diagram 1 - Figure 2). ${ }^{58}$ It is not clear whether this Plan was distributed at the conference as printed material or projected as a slide. What is clear from its reproduction in The Journal of the Royal Institute of British Architects in 1963 is that it was drawn by hand using the standard architectural/engineering drawing instruments of the time: drawing-board with parallel-motion, adjustable set-square, lettering stencils, and some kind of drawing or ruling pen. All subsequent Plans were made using offset lithographic printing processes as the RIBA sought to embed the Plan and the processes it embodies into typical professional architectural practice.

Wooster's justification for the diagram-and its implications of construction systematisation-was the perceived increase in the complexity of the role of the designer: "the designer's role today is a terribly complicated one", he argued, "he is expected to increase productivity; he is expected to produce better buildings; he has got more opportunities and more methods to play with. In the past one man designed everything, and it was fairly easy. Now there is so much to do that it must be systematised" ${ }^{99}$ A core principle of this still nascent Plan was to "codify the things which were similar. The procedures as shown in the chart", he explained, "were similar, but the conditions were different". 60

DIAGRAM 2: 1964

\section{Outline Plan of Work}

\begin{tabular}{llll}
\hline Stage & $\begin{array}{l}\text { Purpose of work and } \\
\text { Decisions to be reached }\end{array}$ & Tasks to be done & $\begin{array}{l}\text { People directly } \\
\text { involved }\end{array}$ \\
\hline
\end{tabular}

A. Inception

To prepare general outline of requirements and plan future action.

B. Feasibility To provide the client with an
appraisal and recsinmeg fol in order that lie may detcrmine

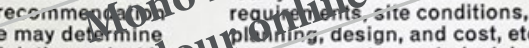
the form in which the projectid 0 Uas necessary to reach decisions. feasible, functicnally, technically and financially.

\begin{tabular}{llll}
\hline $\begin{array}{l}\text { C. Outline } \\
\text { Proposals }\end{array}$ & $\begin{array}{l}\text { To determine general approach } \\
\text { to layout, design and construction } \\
\text { in order to obtain authoritative } \\
\text { approval of the client on the } \\
\text { outline proposals and accom- } \\
\text { panying report. }\end{array}$ & $\begin{array}{l}\text { Develop the brief further. Carry } \\
\text { out studies on user requirements, } \\
\text { technical problems, planning, } \\
\text { design and costs, as necessary } \\
\text { to reach decisions. }\end{array}$ & $\begin{array}{l}\text { All client interests, architec } \\
\text { engineers, QS and speciali } \\
\text { as required. }\end{array}$ \\
\hline $\begin{array}{llll}\text { D. Scheme } \\
\text { Design }\end{array}$ & $\begin{array}{l}\text { To complete the brief and decide } \\
\text { on particular proposals, }\end{array}$ & $\begin{array}{l}\text { Final development of the brief, full } \\
\text { design of the project by architect, }\end{array}$ & $\begin{array}{l}\text { All client interests, architer } \\
\text { engineers, QS and speciali }\end{array}$
\end{tabular}

Figure 3. RIBA Plan of Work for Design Team Operation.

In the same month that Wooster introduced his Plan, the RIBA released the first instalment of its Handbook of Architectural Practice and Management, the very next instalment of which,
All client interests, appoint:architect.

\section{Clients' representatives,} architects, engineers, and QS according to nature of project. engineers, QS and speciali briefing. Conslier requirements, architect. in 1964, would include the first definitive RIBA Plan of Work (Diagram 2 - Figure 3). ${ }^{61}$ At that 
time, it was called Plan of Work for Design Team Operation and included a one-page synopsis in tabular, diagrammatic form, ${ }^{62}$ a look which persisted in all subsequent Plans up until, and including, the current 2013 version (see Diagram 6 - Figure 7). ${ }^{63}$

The initial impetus for the Handbook of Architectural Practice and Management was the publication of The Architect and His Office: A Survey of Organisation, Staffing, Quality of Service and Productivity in 1962. ${ }^{64}$ This document, according to the "Introduction" of the Handbook, first published the following year, "exposed professional failings and showed where [...] weaknesses lay" ${ }^{65}$ "The greatest weakness of architects", the Handbook explains, "is not architectural incompetence, but failure to know how to derive the greatest benefit to their client and society from the resources they enlist-the resources of men, money, materials and methods" ${ }^{66}$ By the application of systematic, scientifically derived management processes, its editorial committee believed that the maximum value would be brought to the broadest possible public. In particular, the Institute's president, Matthew, was in support of the more socialised post-war ethos of "public practice and group working" 67 and certainly endorsed what Glendinning called "Fuller-style synergetic", interdisciplinary practice. ${ }^{68}$ Described by Glendinning as "above all an 'organisation architect", these Plan of Work diagrams represent Matthew's ideal method for controlling "the turbulent political and social cross-currents of the welfare-state-era" ${ }^{69}$ Matthew noted that architects in the US had already had the benefit of a "handbook" of practice systems of their own since $1920,{ }^{70}$ and after the punishing critique of The Architect and His Office, ${ }^{71}$ the production of a UK equivalent had become pressing. ${ }^{72}$

\section{DIAGRAM 3: 1964}

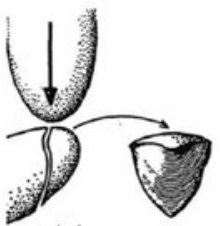

(a)

30

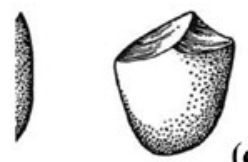

(c)

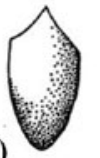

35
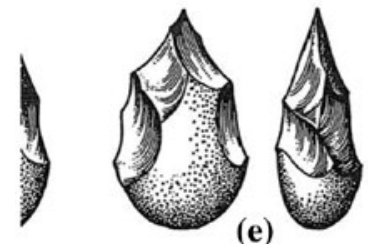

(e)

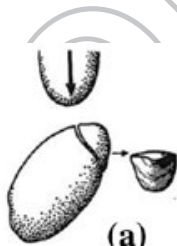

(a)
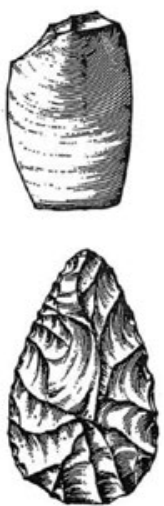

(d)
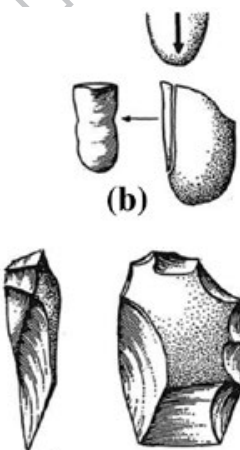

(c)

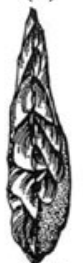

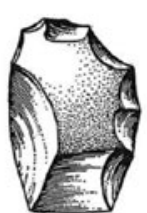

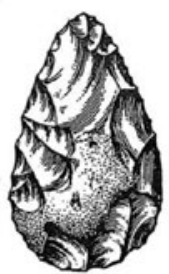

(a)

(b)
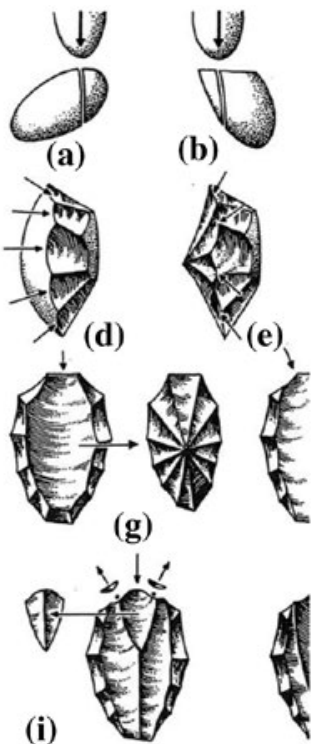

(i)

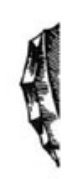

Figure 4. Chaîne opératoire, André Leroi-Gourhan. 
By the time Marie-Louise Inizan, Jacques Tixier, Hélène Roche, and Michel Dauvois had published, in 1995, the last edition of their work on the chaîne opératoire, Technology and Terminology, it had become commonplace in anthropology to understand that it was possible to draw conclusions about broader societal systems through studying its operational sequences (as chaîne opératoire is conventionally translated). Paleo-ethnographers and archaeologists accepted that "knapping is ruled by specific laws pertaining to fracture mechanics, which vary according to the type of stone. Raw materials can be worked directly, or they can be structurally modified beforehand".73 The lithic evidence makes available a more focussed, more intimate understanding of human interaction with those artefacts-a direct connection between "knapping" and "industry". Crucially, it was also becoming better understood that more complex lithic processes, larger scale "projects and the means by which they are implemented [were] subtended by [other] more or less elaborate projects, which can be apprehended through the reconstitution of the associated chaînes opératoire".${ }^{74}$ Furthermore, through the diagramming of multiple operational sequences, an understanding began to emerge that individual acts of knapping might be part of larger networks of construction processes.

It is possible, I would argue then, to compare the early Wooster Plan (Diagram 1 - Figure 2) to the very first RIBA Plan (Diagram 2 - Figure 3) and the first chaine diagrams. ${ }^{75}$ On the one hand, the systematic marshalling of different forces and raw materials in a synthesised process of procurement is present in the schemas represented by both types of diagram, whilst, on the other hand, there is an implicit understanding in the chaîne, right from its beginnings, that these processes were intimate, reciprocating, sometimes circular, but always feeding back into themselves. This is, I would argue, an insight lacking in all Plans of Work from 1963 until 2013 when this began, tentatively, to change.

Rich in hand-drawn illustrations, Diagram 3 (Figure 4) differs from many chaînes that follow and all of the extremely abstracted Plans of Work, most of which have tended to adopt an illustration-free flow-diagram model-the better, perhaps, to "understand complex production systems by revealing, step-by-step, their underlying structure and the relationships and interactions between the elements. ${ }^{76}$ Yet, as I have argued above, the diagram is not only an unmediated reflection of immutable operations - to a very real extent, it makes those operations. In Thinking 30 Between Diagram and Image, Christoph Lueder writes of the dual register of Jackson Pollock's abstract expressionist paintings, which at once sees them as a "record of operational process" as "diagram, but also as image". ${ }^{77}$ For Lueder, "these headings, [diagram and image] rather than indicating rigid categories, designate two opposing vectors, that of explanation and that of imitation". ${ }^{78}$ Crucial to this double reading is the position of the diagram/image: horizontal (laid

35 flat) or vertical (on display). "Thus, a plan drawing displayed vertically", explains Lueder, "will support a reading of it both as record of drawing operations, and as a figure, a representation of a proposed reality". ${ }^{79}$

To understand how chaîne and Plan might share meaningful correspondences, some understanding of the contexts of their development is required-the RIBA's uncritical embrace of technology and Leroi-Gourhan's attempt to account for that technology and its relationship to 
the humans who produce and employ it. Leroi-Gourhan's contemporary, Claude Levi-Strauss, praised Leroi-Gourhan's broad understanding of the "technics" of artefactual production: "one sees that the key idea that governed his [Leroi-Gourhan's] thinking was always to study the interrelations between things rather than the things themselves, to try to reduce the chaotic diversity of the empirical data to invariant relations and to use [...] a method of transformations". ${ }^{80}$ By contrast, it has been a criticism of the various iterations of the architectural Plans of Work that they were, and continue to be, excessively object-orientated. ${ }^{81}$ Bryan Lawson, for example, characterises them as "a description not of the process but of the products of that process". ${ }^{82}$ Allied to the Plan of Work's overweening focus on "deliverables", it appears, at times, that there is little sense of what it might mean for the "system" if and when those deliverables got fed back into it. Conversely, "the project", Inizan explains of the chaine, "includes a conceptual scheme, of an intellectual nature, which is itself implemented through a series of operations". ${ }^{83}$

DIAGRAM 4: 1978

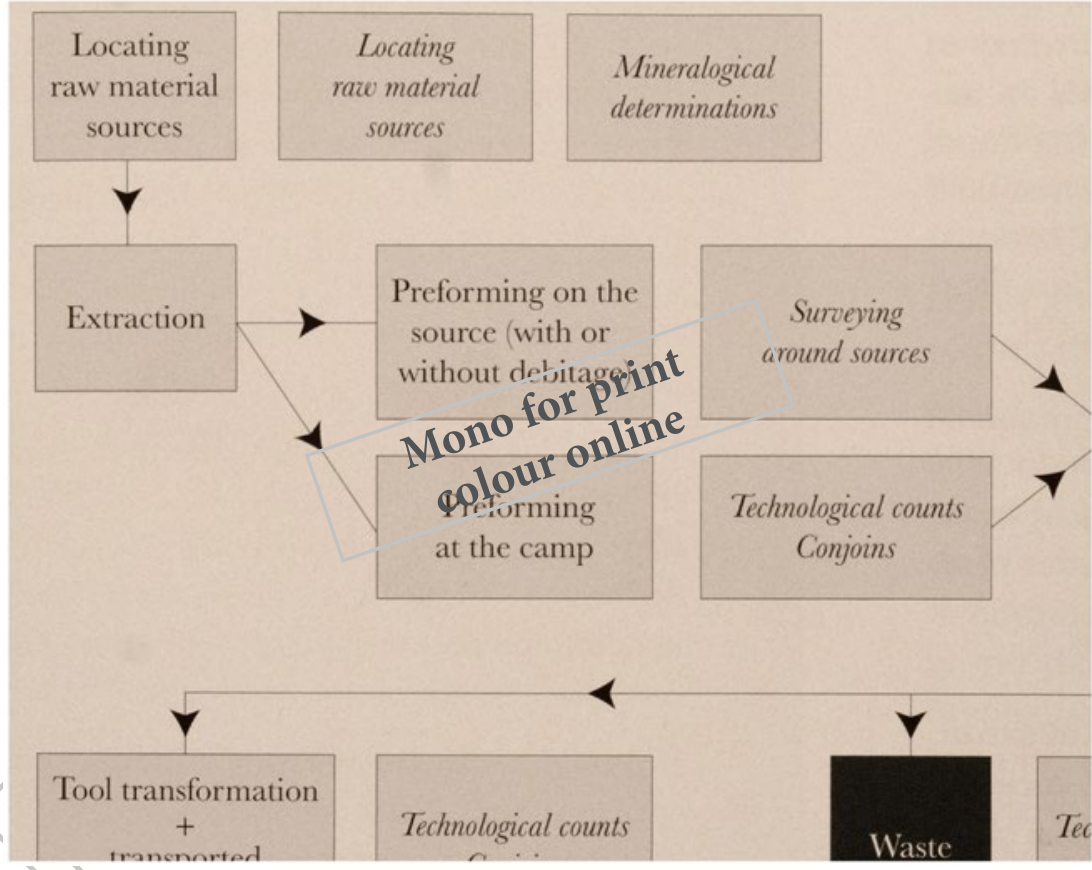

Figure 5. Chaîne opératoire, Jacques Tixier.

The chaine, through its intimate, gestural example, demands of the Plan an engagement with the human body it ignores and the reciprocating afterlife of the buildings it occludes. In his doctoral thesis of 1978 (Diagram 4 - Figure 5), ${ }^{84}$ Jacques Tixier produced a diagram which appears to be the conceptual descendent of Leroi-Gourhan's chaîne opératoire, and the direct ancestor to the many detailed chaîne opératoire diagrams which followed. ${ }^{85}$ This diagram both concretises Leroi-Gourhan's human/technical schema and explores complex temporal modes: 
Leroi-Gourhan's narrative is one of an increasing complexity in the "sequence of operations" [...] which constitutes different layers of anticipation and of memory. We move from survival-instinct (fight-or-flight mechanism) to reflection (upon what makes a good tool, how it might be used in the future, how it might be improved, how one goes about achieving this with efficiency, and so on); in other words, the human's relation to the world changes from purely concrete (i.e. animal, determined by genetic programming) to one which incorporates increasing levels of abstraction (i.e. memory and foresight). ${ }^{86}$

Certainly, Stiegler understood the temporal power of Leroi-Gourhan's project and, in Technics and Time 1: The Fault of Epimetheus, used temporal aspects of the mythology surrounding the Greek deity, Epimetheus, to interrogate that work: "in classical Greek culture a mythology of the origin of technics is to be found which is also a mythology of the origin of mortality, a thanatology" ${ }^{87}$ Stiegler relates the story of Prometheus the Titan, who is associated with "forethought", and his brother, Epimetheus, the Titan associated with "afterthought" ${ }^{8}$ Here is Plato's account of how Epimetheus wasted his brother's, and mankind's, gifts:

Now Epimetheus, being not so wise as he might be, heedlessly squandered his stock of properties on the brutes; he still had left unequipped the race of men, and was at a loss what to do withit. As he was casting about, Prometheus arrived to examine his distribution, and saw that whereas the other creatures were fully and suitably provided, man was naked, unshod, unbedded, unarmed; and already the destined day was come, whereon man like the rest should emerge from earth to light. 89

For Stiegler, our need for tools is the fault of Epimetheus: "his [our] condition will be to supplement this default of origin by procuring for himself prostheses, instruments". ${ }^{0}$ Thereafter (at least until the Industrial Revolution), humans and their development of culture and technics have kept pace with one another. In this way, just as humans become technical, Ingraham observes that "tools, and the constructions made possible by tools are a series of extruded bio-anatomical and bio-neurological structures".91 For Audouze, Leroi-Gourhan "could give up the artificial division he had initially accepted between Homo faber and Homo sapiens [...] and explore instead the continuity he perceived from animal to human in the technological realm". ${ }^{2}$ According to Ingraham, for anthropologists, "as tools take over evolutionary development from the body, the crude primal hammers and knives increase in sophistication and eventually both produce and themselves evolve into complex mechanisms that mediate between the hand that pushes a button, the machine that cuts the cloth and so forth". ${ }^{93}$ Both the Plan and the chaine may be cast, in this view, as "artificial organs", exteriorising that which is normally interior, "extend[ing] and exterioriz[ing] the body in space". ${ }^{44}$ Ingraham further describes how "LeroiGourhan brings the tool, hand, posture, face and theories of evolution into such an intimate, 
and such a literal, developmental relationship", ${ }^{95}$ a condition which doesn't seem to apply to either the chaine diagrams which followed Leroi-Gourhan or to any version of the Plan at all. For Leroi-Gourhan, the body of Homo faber, rather than becoming redundant, diffuses itself out into the world, through technology, into tools.
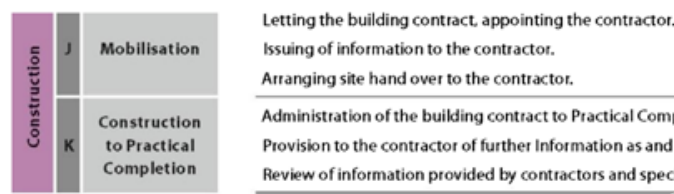

Figure 6. RIBA Outline Plan of Work.

Bryan Lawson wrote of architects' design process diagrams, amongst which he includes the Plan of Work, that they consist of "a sequence of distinct and identifiable activities which occur in some predictable and identifiably logical order" ${ }^{96}$ Yet, this characterisation is not, in this case, borne out by reading the thoughts of the authors of the Plan of Work. "Predictability", at least, may be an understandable conclusion to draw if based purely upon the evidence of the diagrams themselves. Indeed, the power of the misunderstood diagram of the Plan, through all of its iterations, often makes the building its own, teleological, object. As Frascari says, "architecture is based on geometric acts of prediction which are used to evoke future constructions".97 On this account, the building already exists in a liminal state, waiting for the documents of architecture to summon it forth. Frascari describes the "mantic" nature of architectural practice, the "divinatory" power of drawing to produce architecture: "like histories, architectural projections are attempts to make the future constructions available and usable. They are quite literally 'self-fulfilling' prophecies" ${ }^{98}$ The "architecture" prophesied in the RIBA Plan of Work confronts the chaine with Frascari's "geometric acts" and "architectural projections", demanding that it reveal its otherwise occluded propositional character.

In 2013, another attempt was made by the RIBA to fundamentally change their Plan of Work. In part, this was a delayed reaction to the devastating critique of uneconomic and adversarial UK construction practices in both the Latham (1994) and Egan (1998) Reports, ${ }^{99}$ and in part, an attempt to better reflect profound changes in the way buildings were being procured, in particular the new-found hegemony of "design and build" and, later, Building Information Modelling 
(BIM) processes of organising the construction of buildings. But this reaction was still built upon the linearity of the old "Outline" of 2007 (Diagram 5 - Figure 6), which had singularly failed to address any of these issues. What had begun to shift, however, was the central position that design had always had, both implicitly and explicitly, within the earlier Plans-a position now being squeezed by a new (perhaps inevitably, given Latham and Egan) emphasis, instead, upon construction and administrative processes. In this view, the Plan may be a reflection of design processes (and the analysis below reveals them still to be significant), but must also be, according to W.P. Hughes, a tool for "managing the process [of] construction projects", ${ }^{100}$ developments which would, no doubt, have pleased Robert Matthew.

DIAGRAM 6: COMPARISON OF THE RIBA PLAN OF WORK 2013 WITH CHAÎNES OPÉRATOIRES

Here I will break the strict order of the chaîne/Plan chronology to allow three chaîneand Plan diagrams to begin to reveal their respective correspondences and occlusions.

At the top of Diagram 6 (Figure 7) is a chaîne opératoire by Claudine Karlin and Michèle Julien. The version of the chaîne illustrated by Karlin and Julien is typical of the type in its aims and general organisation, and includes phases covering "procurement", "preparation", and "blade production". ${ }^{101}$ To its right is Roger Grace's simplified, pedagogic version explaining the basic principles of the "operational sequence". ${ }^{102}$ Below the two chaine diagrams is illustrated the RIBA's current Plan of Work. Karlin and Julien's reciprocating complexes of operation recall Leroi-Gourhan's pictorial chaîne (Diagram 3) together with its own convolutions including "entries such as elementary means and forces". These means and forces include "prehension, percussions to break, cut, or shape; fire to heat, cook, melt, dry, and bend; water to mix, melt, soften, wash, and to use in different solutions to tan or preserve; and air to dry, clean, or stir up fire". ${ }^{103}$ These may be generic operations, but they are also implicitly gestural actions - a feature of Plans of Work which is so occluded that it is only revealed when they are interrogated using the chaîne opératoire as a tool to prise them open. For example, the term "prepare" is a favourite in Plans of Work, disguising within its brevity, notions of careful making, alongside an active sense of "getting ready".

The RIBA Plan of Work 2013 is more complex, more embedded in normative building 30 construction processes, but its language betrays resemblances to the chaîne opératoire: "procurement" (identical), "preparation" (identical), and "construction" (instead of "production") are likewise mentioned. The chaine formulated by Roger Grace also describes processes of "procurement", "technology" (instead of "production" or "construction"), and "use" (included in the Plan of Work, but omitted in the Karlin and Julien chaîne). There are other differences

35 too, of course: the Plan of Work describes itself as concerning "building projects", whilst the chaîne opératoire incorporates language particular to "blade production". It might seem that this comparison, therefore, fatally incorporates a category mistake; the Plan of Work is a tool architects and other construction practitioners use to make buildings, whereas the chaîne opératoire merely describes an already, and usually long-ago, completed process. Yet, I would argue that the life-cycle of a building is as affected by the structures described in the Plan of Work as 
TECHNICAL SCHEME

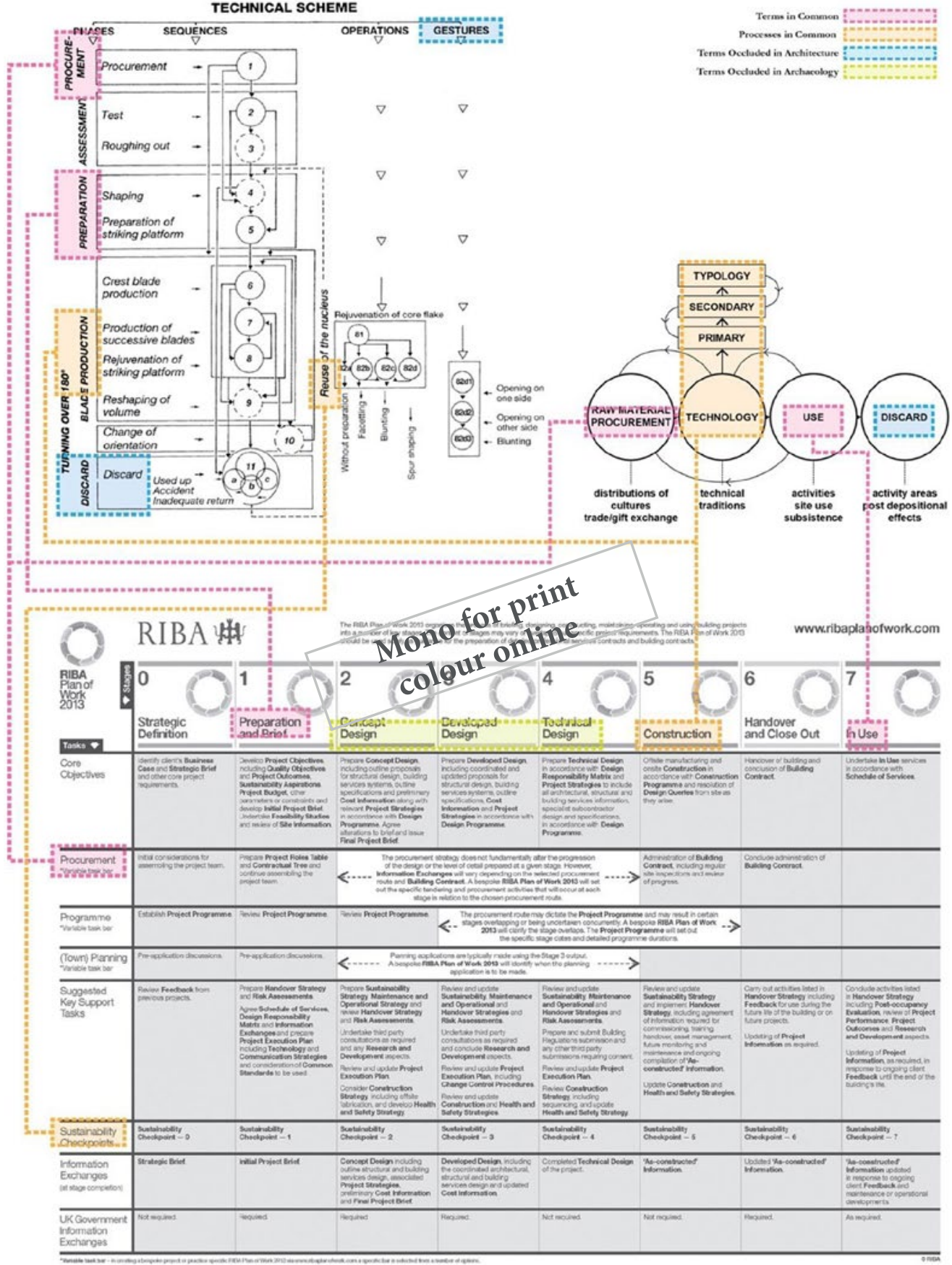

Figure 7. Top left: Technical scheme, Claudine Karlin and Michèle Julien, 1994. Top right: Chaîne opératoire, Roger Grace, 2012 [1997]. Bottom: RIBA Plan of Work 2013. 
is the life-cycle of the Magdalenian period blade ${ }^{104}$ analysed by Karlin and Julien; the architect imposes their design practices just as the archaeologist imposes their reconstructive practices. To a very real extent, the Plan of Work makes the building just as the chaine opératoire makes the stone tool. To requote Frascari regarding architecture, "using these analogous instruments, the opportunity for a project is developed. This is not simply a spatial procedure, but a mantic operation requiring careful timing and specific opportunities". ${ }^{105}$ The yet-to-be-used building and the used-once-upon-a-time Magdalenian blade are made anew through the "mantic [...] opportunities" provided by the Plan and the chaine. Alternatively, for Anthony Vidler, it is the non-representational characteristics of the diagram per se (rather than Frascari's analogous ones), its "abstraction that allows the diagram to be, so to speak, productive, so that through permutation and transformation, the characters of one diagram may appear in another. In this sense the diagram is both the instrument of thought and its mirror". 106

It is possible to see that "Discard", for example, is present and indeed crucial to the chaine opératoire but absent in the Plan; except as investment opportunities, the place of the discarded, empty building is occluded in the kind of architectural practice typically represented by the RIBA Plan of Work. The Plan, in this, its most recent incarnation, refers to categories of "In Use" and "post-occupancy", but these denote periods of occupancy immediately post-handover of a completed building — not to periods of dereliction, decay, and ruin. More centrally, I would argue that the notion of design is profoundly occluded in archaeology, yet manifests itself most prominently, though usually undetected, in various practices of reconstruction. And, indeed, one can see from these diagrams that the "design" categories in the architectural Plan are entirely missing from, or occluded in, the archaeological chaîne.

For Leroi-Gourhan, the various diagrammed chaînes which followed Le Geste et la Parole must have seemed like a failure of the seamless body/tool integration he sought; "the prosthesis", wrote Stiegler, the fused tool/body, "is the origin of inequality. The man of pure nature has everything about himself, carries himself whole and entire about himself [...] no fissure is at work in him that would be provoked by a process of differentiation on the outside of himself". 107

Born from a paleo-ethnographic concern with the reconstruction of ancient societies from archaeological evidence, the chaîne does its work upon incomplete evidence, just as the design work of the architect is done upon necessarily incomplete input. For the architect, these fragments may be characterised as: "brief" (often proposals from a client for a building), "context" (the physical, historical, political, social, and economic environment from which a design and any subsequent building might emerge), and "tectonics" (the way a design and any subsequent building might be put together). For the archaeologist, there is analogous fragmentary evidence 35 in processes of excavation, assemblage, and find. And the collection and use of these fragments for the archaeologist faces the past (what did the building look like to which these fragments belonged?) and for the architect faces the future (what will the building look like to which these fragments belong?), an echo of Stiegler's forward and backward facing-Promethean and Epimethean-temporal registers. I would argue that this conceals the over-arching propositional character of both design and reconstruction. I have also suggested that, like Frascari's "mantic" 
or divinatory process, both the architect and the archaeologist in fact practise acts of propositional making, performed in the present through the indexical relationship between designer and artefact. That is, at the moment of enquiry - in the present-there is no building, but the design, just like the reconstruction, proposes one. If architecture is a design-centred discipline which proceeds by suggesting propositional constructions, then archaeology also designs, but in the form of reconstructions. All such resemblances share homological similarities of interconnected disciplinary origin.

The Plan, with its impersonal reductiveness relaxed, and the chaine, with its occluded "propositional" character revealed, "offer", as Latour, that other great anthropologist of human praxis, might have interjected into this conversation, "a certain way of loading an entity into another by making the second attentive to the first, and by making both of them diverge from their usual path, their usual interpretation". ${ }^{108}$ Or, as Deleuze put it, "thus there is no diagram that does not also include, besides the points which it connects up, certain relatively free or unbound points, points of creativity, change and resistance, and it is perhaps with these that we ought to begin in order to understand the whole picture". ${ }^{109}$

About the Author: Alessandro Zambelli is an architect and co-founding director in 2000 of Bates Zambelli Architects. Currently a lecturer and a researcher at the University of Brighton, his $\mathrm{PhD}$ at the Bartlett School of Architecture, Scandalous Artefacts: Visual and Analogical Practice between Architecture and Archaeology, was supervised across the departments of architecture and anthropology.

Disclosure Statement: No potential conflict of interest was reported by the author.

ORCID: Alessandro Zambelli (iD http://orcid.org/0000-0001-8647-3877

\section{NOTES}

1. Andrew George Derbyshire and J. M. Austin-Smith, The Architect and His Office. A Survey of Organisation, Staffing, Quality of Service and Productivity Presented to the Council of the Royal Institute on 6th February, 1962, London: RIBA, 1962, 6.150. Also used as the opening quotation to: J. A. Powell (ed.), Handbook of Architectural Practice and Management: 3 rd Instalment, $1^{\text {st }}$ edn, London: RIBA, 1965, 1.

2. André Leroi-Gourhan, Gesture and Speech, Cambridge, MA/London: MIT Press, 1993 (original French edition 1964-1965), 91.

3. Diagram presented by C. E. D. Wooster to the conference; J. M. Austin-Smith, "The Architect and Productivity [Conference Proceedings]", RIBA Journal, 70, no. 10 (1963), 404-405 [detail]. 4. Anthropology and archaeology share a complex disciplinary relationship. In the US, anthropol- 
physical anthropology, and cultural anthropology. In the UK, archaeology tends to be treated as a separate discipline.

5. Alessandro Zambelli, "Scandalous Artifacts: Practice between Archaeology and Architecture", Architecture and Culture, 1, nos 1-2 (2013).

6. Miles Glendinning, Modern Architect: The Life and Times of Robert Matthew, London: RIBA Pub., 2008, back matter.

7. Becky Conekin, The Autobiography of a Nation: The 1951 Festival of Britain, Manchester: Manchester University Press, 2003.

8. Conekin, The Autobiography of a Nation, 4.

9. Donald Gibson, "Inaugural Address of the President", RIBA Journal, 71, no. 12 (1964), 343.

10. Glendinning, Modern Architect, 311.

11. Glendinning uses single inverted commas here, but it is unclear who he is quoting. I have taken this, therefore, to be the generalised view of the RIBA membership rather than necessarily Glendinning’s own. Glendinning, Modern Architect, 310.

12. Erwan Dianteill, "Cultural Anthropology or Social Anthropology? A Transatlantic Dispute" [“Anthropologie culturelle ou anthropologie sociale ? Une dispute transatlantique”], L’Année sociologique, 62, no. 1 (2012), 93.

13. Dianteill, "Cultural Anthropology or Social Anthropology?”, 94.

14. Edmund R. Leach, "Glimpses of the Unmentionable in the History of British Social Anthropology”, Annual Review of Anthropology, 13 (1984), 1-23.

15. Dianteill, “Cultural Anthropology or Social Anthropology?”, 103.

16. Dianteill, "Cultural Anthropology or Social Anthropology?”, 109.

17. Richard P. Werbner, "The Manchester School in South-Central Africa”, Annual Review of Anthropology, 13 (1984), 164.

18. Françoise Audouze, "Leroi-Gourhan, a Philosopher of Technique and Evolution", Journal of Archaeological Research, 10, no. 4 (2002), 278-279.

19. Gilles Deleuze, Foucault, London: Continuum, 2006, 30.

20. Christoph Lueder, "Diagram Ecologies_Diagrams as Science and Game Board”, in Philip Cox, Beryl Plimmer, and Peter Rodgers (eds), Diagrammatic Representation and Inference: 7th International Conference, Diagrams, Canterbury: Springer, 2012, 215.

21. Tim Ingold, "Life in a World without Objects", O-Zone: A Journal of Object-Oriented Studies, no. 1 (2014), 182.

22. Tim Ingold, Lines: A Brief History, London: Routledge, 2007.

23. Lines.

24. Lines, 263.

25. André Leroi-Gourhan, ÉVolution Et Techniques I-L'homme Et La Matière, Vol. 1, Sciences D'aujourd'hui, 2nd edn, Paris: A. Michel, 1971, 319, in Audouze, "Leroi-Gourhan", 288. This is presumably Audouze's translation into English.

26. Marco Frascari and William Braham, "On the Mantic Paradigm in Architecture: The Projective Evocation of Future Edifices", Proceedings of the Association of Collegiate Schools of Architecture Annual Meeting, Montreal: ACSA, 1994, 265. 
27. For commentary on anthropology as an "umbrella" humanities discipline, see, for example, Gavin Lucas, “The Mobility of Theory”, Current Swedish Archaeology, 23 (2015), 13-32; Ina-Maria Greverus, "Anthropological Horizons, the Humanities and Human Practice", Anthropological Journal on European Cultures, 1, no. 1 (1990), 13-33. For architect Walter Gropius' desire to see an "alliance of the arts under the wing of great architecture", see Ulrich Conrads, Programmes and Manifestoes on 20th-Century Architecture, Cambridge, MA/London: MIT Press, 1971. See also Lewis Mumford's assertion of architecture as "the commanding art" in Lewis Mumford, The Culture of Cities, London: Routledge, 1997.

28. Mark Cousins, "Building an Architect”, in Jonathan Hill (ed.), Occupying Architecture: Between the Architect and the User, London: Routledge, 1998, 10.

29. I recall that it was 2008 , but the precise words spoken are lost to my memory and I am reluctant to disclose the identities of the interlocutors.

30. André Leroi-Gourhan, "Review of: The Eternal Present: The Beginnings of Art: A Contribution on Constancy and Change, Vol. 1: by S. Giedion", American Anthropologist, 65, no. 5 (1963), 1181. 31. Sigfried Giedion, The Eternal Present: The Beginnings of Art: A Contribution on Constancy and Change, the A. W. Mellon Lectures in the Fine Arts. 1957, Etc., London: Oxford University Press, 1962.

32. Leroi-Gourhan's relationship with Giedion had faltered over the former's view that Giedion's treatment of prehistoric art was "quasi-photographic", that he failed to "penetrate into the fundamental discontinuities of each chronological layer or geological stratum from which the particular representations were extracted". Spyros Papapetros, "Modern Architecture and Prehistory: Retracing the Eternal Present (Sigfried Giedion and André Leroi-Gourhan)", RES: Anthropology and Aesthetics Wet/Dry, no. 63/64 (spring/autumn 2013), 183.

33. Leroi-Gourhan doesn't use the term Homo faber, instead he refers to "palaeoanthropians". Leroi-Gourhan, Gesture and Speech, 115. Stiegler's use of the term is more like Henri Bergson's in the sense of it defining a general ontological condition rather than a group of proto-human species: Henri Bergson, Creative Evolution, New York: Henry Holt and Company, 1913, 139; Bernard Stiegler, Technics and Time 1: The Fault of Epimetheus, trans. Richard Beardsworth and George Collins, Stanford, CA: Stanford University Press, 1998.

34. Audouze, "Leroi-Gourhan", 280.

35. Colin Renfrew and Paul G. Bahn, Archaeology: Theories, Methods and Practice, $3^{\text {rd }}$ edn, London: Thames \& Hudson, 2000, 388.

36. Soressi and Geneste, "Special Issue: Reduction Sequence, Chaîne Opératoire, and Other Methods: The Epistemologies of Different Approaches to Lithic Analysis. The History and Efficacy of the Chaîne Opératoire Approach to Lithic Analysis: Studying Techniques to Reveal Past Societies in an Evolutionary Perspective”, PaleoAnthropology, 2011 (2011), 334-50.

37. André Leroi-Gourhan, Le Geste et la Parole 1: Technique et Language, Paris: Albin Michel, 1964.

38. Jacques Tixier et al., Préhistoire De La Pierre Taillée 1 Terminologie Et Technologie, Antibes: CREP, 1980.

39. Marie-Louise Inizan et al., Technology and Terminology of Knapped Stone, trans. Jehanne FéblotAugustins, Vol. 5, Préhistoire De La Pierre Taillée, Nanterre: CREP, 1999, 14. 
40. Renfrew and Bahn, Archaeology, 388.

41. Zambelli, "Scandalous Artifacts".

42. Leonard Beaven et al. (eds), Architect's Job Book: Vol. 1: Job Administration, $5^{\text {th }}$ edn, London: RIBA Publications, 1988.

43. W. P. Hughes, "A Comparison of Two Editions of the Riba Plan of Work", Engineering, Construction and Architectural Management, 10, no. 5 (2003), 302-11.

44. In particular, the Plan of Work is very similar to schema used in other Commonwealth countries, for example both the Australian Institute of Quantity Surveyors and Australian Institute of Architects publish versions of their own. Australian Institute of Quantity Surveyors (ed.), Australian Cost Management Manual, Canberra, ACT: Australian Institute of Quantity Surveyors, 2000; and Jim Smith et al., Building Cost Planning for the Design Team, $3^{\text {rd }}$ edn, Abingdon: Routledge, 2016, 36-37.

45. Audouze, "Leroi-Gourhan”, 283.

46. Quoted in Audouze, "Leroi-Gourhan”, 283.

47. Glendinning, Modern Architect, back matter.

48. Leroi-Gourhan, Gesture and Speech, 20.

49. Catherine Ingraham, Architecture, Animal, Human. The Asymmetrical Condition, London: Routledge, 2006, 232.

50. Ingraham, Architecture, Animal, Human, 232.

51. Leroi-Gourhan, Gesture and Speech, 239.

52. Leroi-Gourhan, Gesture and Speech, 243.

53. Leroi-Gourhan, Gesture and Speech.

54. Alexandra Trevisan, "A Travelling Theatre", in Jorge Palinhos and Maria Helena Maia (eds), Dramatic Architectures: Places of Drama-Drama for Places, Escola Superior Artística do Porto, Portugal: Centro de Estudos Arnaldo Araújo da CESAP/ESAP, 2014, 522.

55. The $6^{\text {th }}$ UIA Congress was held in London in 1961 during the presidency of the Soviet Union. The presidency passed to the UK the following year for a two-year period before passing to Cuba. General Secretariat of the International Union of Architects, "UIA: Congresses", http://www.uia-architectes.org/en/s-informer/congres/tous-les-congres\#.WWs3G9PyuV4 (accessed 16 July 2017).

56. J. Christopher Jones and D. G. Thornley, Design Methods: Conference on Systematic and Intuitive Methods in Engineering, Industrial Design, Architecture and Communications: Selected Papers, Oxford:Pergamon Press, 1963.

57. Nigel Cross, Designerly Ways of Knowing, London: Springer, 2006, 119.

58. Austin-Smith, “The Architect and Productivity”, 404-405.

59. Austin-Smith, “The Architect and Productivity”, 405.

60. Austin-Smith, “The Architect and Productivity”, 407.

61. R. A. Green and W. A. Watson (eds), Handbook of Architectural Practice and Management: 1st Instalment, $1^{\text {st }}$ edn, London: RIBA, 1963; Powell, J. A., and W. A. Watson (eds), Handbook of Architectural Practice and Management: 2nd Instalment. 1st ed. London: RIBA, 1964. 
62. Powell, Handbook of Architectural Practice and Management: 2nd Instalment, 3:220.

63. RIBA, “Riba Plan of Work 2013”, London: RIBA, 2013.

64. Derbyshire and Austin-Smith, The Architect and His Office.

65. Powell, "Introduction", Handbook of Architectural Practice and Management: 3rd Instalment, 5.

66. Powell, "Introduction", Handbook of Architectural Practice and Management: 3rd Instalment, 5.

67. Glendinning, Modern Architect, 134.

68. Glendinning, Modern Architect, 308.

69. Glendinning, Modern Architect, front matter.

70. American Institute of Architects, The Architect's Handbook of Professional Practice, $15^{\text {th }}$ edn, Hoboken, NJ: Wiley, 2014.

71. Derbyshire and Austin-Smith, The Architect and His Office.

72. Glendinning, Modern Architect, 311.

73. Glendinning, Modern Architect, 311.

74. Glendinning, Modern Architect, 311.

75. Alongside those of Jacques Tixier (see Diagram 5 below), diagrams by Pierre Lemonnier and Jean-Michel Geneste (not illustrated here) are also early and significant: Pierre Lemonnier, Les Salines De L'ouest Logique Technique, Logique Sociale, ed. Presses universitaires de Lille Maison des sciences de l'homme, Travaux Et Documents, Paris/Lille: Éditions de la Maison des sciences de l'homme, presses universitaires de Lille, 1980; and Jean-Michel Geneste, Analyse Lithique D'industries Moustériennes Du Périgord: Une Approche Technologique Du Comportement Des Groupes Humains Au Paléolithique Moyen, Dordogne: University of Bordeaux, 1985.

76. Urs A. Meyer, Simone E. Creux, and Andrea K. Weber Marin, Process Oriented Analysis: Design and Optimization of Industrial Production Systems, Boca Raton, FL/CRC/London: Taylor \& Francis [distributor], 2007, 38.

77. Christoph Lueder, "Thinking between Diagram and Image: The Ergonomics of Abstraction and Imitation”, Architectural Research Quarterly, 15, no. 1 (2011), 58.

78. Lueder, "Thinking between Diagram and Image".

79. Lueder, "Thinking between Diagram and Image".

80. Audouze, "Leroi-Gourhan", 282. Translation from French, presumably by Audouze, in: Jacques Lombard, “André Leroi-Gourhan Ou Les Voies De L'homme. Actes Du Colloque Du Cnrs”, Revue française de sociologie, 30, no. 2 (1989), 350.

81. It is interesting to note that the current 2013 incarnation of the RIBA Plan of Work is, according its creators, based upon the Construction Industry Council (CIC) project stages. Yet, in The CIC Scope of Services Handbook of 2007, the CIC is at pains to point out how its plan, in its turn, maps seamlessly onto the RIBA Plan of Work 2007. Not only is the CIC's scope of services object-orientated, as Lawson observed was the case with the RIBA Plan, but it is also explicitly 'outcomes'-orientated, prominently highlighting its intention of facilitating, for example, "deliverables at each stage". Construction Industry Council (ed.), The CIC Scope of Services Handbook, $1^{\text {st }}$ edn, London: RIBA Publishing, 2007. An observation which might just as readily be made about the processes described in Diagram 3 whose pictorial medium - its beautifully drawn lithic 
artefacts - reveals its own 'deliverables' orientation. These pictorial analyses presage further systematisations to follow-from Leroi-Gourhan himself, but then also, and most prominently, from Pierre Lemonnier and Tixier.

82. Bryan Lawson, How Designers Think: The Design Process Demystified, $4^{\text {th }}$ edn, Amsterdam/ London: Architectural Press [Elsevier], 2006, 36.

83. Inizan et al., Technology and Terminology of Knapped Stone, 5, 15.

84. Tixier et al., Préhistoire De La Pierre Taillée 1: Terminologie Et Technologie, 130. Many thanks to Norah Moloney for bringing this diagram to my attention.

85. A very similar tradition, often called the "reduction sequence", had already existed in the United States from the early twentieth century. See, for example: Peter Bleed, “Trees or Chains, Links or Branches: Conceptual Alternatives for Consideration of Stone Tool Production and Other Sequential Activities", Journal of Archaeological Method and Theory, 8, no. 1 (2001), 101-27.

86. Toby Bennett, "Week 7-the Invention of the Human (Pt. 2)”, https://readingtechnics.wordpress. com/2013/08/28/week-7-the-invention-of-the-human-pt-2/ (accessed 16 July 2017).

87. Stiegler, Technics and Time 1, 16.

88. Henry George Liddell et al., A Greek-English Lexicon, 9th edn, Oxford: Clarendon Press, 1940,

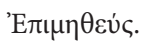

89. Plato, Plato in 12 Volumes, Vol. 3, trans. W. R. M. Lamb, Cambridge, MA/London: Harvard University Press \& William Heinemann Ltd, 1967, 321b-321c.

90. Stiegler, Technics and Time 1, 114.

91. Ingraham, Architecture, Animal, Human, 232.

92. Audouze, 288.

93. Ingraham, Architecture, Animal, Human, 235.

94. Ingraham, Architecture, Animal, Human, 234.

95. Ingraham, Architecture, Animal, Human, 235.

96. Lawson, How Designers Think, 33.

97. Frascari and Braham, "On the Mantic Paradigm in Architecture", 262.

98. Frascari and Braham, "On the Mantic Paradigm in Architecture", 263.

99. Michael Latham, Constructing the Team: Final Report of the Government/Industry Review of Procurement and Contractual Arrangements in the UK Construction Industry, London: HMSO, 1994. John Egan, Rethinking Construction: The Report of the Construction Task Force, London: Department of Trade and Industry, 1998.

100. Hughes, "A Comparison of Two Editions of the Riba Plan of Work", 303.

101. I am yet to analyse the 'Assessment" phase which may be akin to processes of prototyping, common in some forms of design practice, but not in architecture.

102. Roger Grace, Chaîne Opératoire, Ikarus Books, 2012, 28.

103. Leroi-Gourhan, ÉVolution Et Techniques I - L'homme Et La Matière. Sciences D'aujourd'hui, 1971, 18-19, in Audouze, "Leroi-Gourhan, a Philosopher of Technique and Evolution”, 2002, 283. This is presumably Audouze's own translation into English. 
104. c.16,000 to 12,000 years ago in western Europe. Paul G. Bahn, The Penguin Archaeology Guide, London: Penguin, 2001, 272.

105. Frascari and Braham, "On the Mantic Paradigm in Architecture”, 265.

106. Anthony Vidler, "What Is a Diagram Anyway?”, in Peter Eisenman and Silvio Cassarà (eds), Peter Eisenman: Feints, Milan: Skira, 2006, 20.

107. Stiegler, Technics and Time 1, 116.

108. Bruno Latour, “A Well-Articulated Primatology: Reflexions of a Fellow Traveller," in Shirley Strum and Linda Marie Fedigan (eds), Primate Encounters: Models of Science, Gender, and Society, Chicago, London: University of Chicago Press, 2000, 15. 109. Deleuze, Foucault, 37. 